\title{
Fucoxanthin identification and purification of brown algae commonly found in Lombok Island, Indonesia
}

\author{
YENI SULISTIYANI ${ }^{1, \boldsymbol{v}}$, AGUS SABDONO ${ }^{2}$, NORMA AFIATI ${ }^{1}$, HAERUDDIN $^{1}$ \\ ${ }^{1}$ Department of Aquatic Resource Management, Faculty of Fisheries and Marine Science, Universitas Diponegoro. Jl. Prof. H. Soedarto, SH, Tembalang, \\ Semarang 50275, Central Java, Indonesia Tel.: +62-24-7474698, ‘email: yen.sulis@ gmail.com \\ ${ }^{2}$ Department of Marine Science, Faculty of Fisheries and Marine Science, Universitas Diponegoro. Jl. Prof. H. Soedarto, SH, Tembalang, Semarang \\ 50275, Central Java, Indonesia
}

Manuscript received: 18 November 2020. Revision accepted: 27 February 2021.

\begin{abstract}
Sulistiyani Y, Sabdono A, Afiati N, Haeruddin. 2021. Fucoxanthin identification and purification of brown algae commonly found in Lombok Island, Indonesia. Biodiversitas 22: 1527-1534. Fucoxanthin is a significant carotenoid pigment found in brown algae. Fucoxanthin is the most human-exploited pigment in brown algae due to its health benefits such as antioxidant, anti-diabetic, anti-obesity, anti-cancer, and anti-inflammatory activities. Therefore, fucoxanthin has been mass-produced on an industrial scale as a food supplement. This work focused on identifying, purifying and comparing the fucoxanthin yield diversity at one study site quantitatively. Three brown algae commonly found in Lombok waters have been studied in this work: Sargassum cf. granuliferum, Sargassum polycystum, and Sirophysalis trinodis. Fucoxanthin was successfully identified using HPLC methods, TLC and Spectra absorption analysis. Using HPLC, fucoxanthin was identified at $450 \mathrm{~nm}$ wavelength, with a retention time of 3.088-3.095 min. Based on the TLC result, the Rf value of fucoxanthin is 0.46-0.47, while the spectra absorption maxima are 447.6-448.4 nm. The highest fucoxanthin yield was found in $S$. polycystum, followed by $S$. cf. granuliferum and Sirophysalis trinodis with $3.01 \pm 0.01 \mathrm{mg} / \mathrm{g}, 2.21 \pm 0.002 \mathrm{mg} / \mathrm{g}$, and $0.95 \pm 0.01 \mathrm{mg} / \mathrm{g}$, respectively.
\end{abstract}

Keywords: Fucoxanthin, Lombok, Sargassum cf. granuliferum, Sargassum polycystum, Sirophysalis trinodis

\section{INTRODUCTION}

Numerous previous studies have revealed many secondary metabolites produced by brown algae (family Phaeophyceae). These metabolites are alginate (Fertah et al. 2017; Setyawidati et al. 2018; Wen et al. 2016), laminarin (Kadam et al. 2015), fucoidan (Zorofchian Moghadamtousi et al. 2014), phlorotannin (Stiger-Pouvreau et al. 2014), diterpene (El Shoubaky and Salem 2014), bromophenol (Shi et al. 2010), oxylipin (Ritter et al. 2008), glycoprotein (Go et al. 2010), fucan (Will Castro et al. 2016), chromene (Kim et al. 2012), a polyphenol (Tanniou et al. 2014), and fucoxanthin (Zhang et al. 2015). Fucoxanthin is an orangecolored pigment that gives a brownish color to brown algae and has high biological activity. This compound has a unique structure, containing Alene and 5,6-monoepoxide bonds (Yip et al. 2014). It is produced from carotenoid pigments' biosynthesis, and $10 \%$ of total carotenoids are found in marine waters (Peng et al. 2011). Fucoxanthin plays an essential role in photosynthesis, besides chlorophyll. Among many brown algae species, Sargassum species are well known as a source of fucoxanthin, whereas Sirophysalis sp. is hardly known.

Technically, marine seaweed taxa are divided by their pigment contents. Pigments are bioactive materials classified into secondary metabolite categories involved in environmental biotic and abiotic stress response (Muranaka and Saito 2010). In brown algae, fucoxanthin is a specific carotenoid pigment, which is the primary orange-brown pigment in addition to chlorophyll a, chlorophyll $\mathrm{c}$, and $\beta$ - carotene (El Gamal 2010). It plays an important role together with the chlorophyll in photosynthesis (Mikami and Hosokawa 2013). Recently, fucoxanthin has attracted attention because of its essential role in health issues.

Several studies have proposed that fucoxanthin is a highly bioactive compound. Its activities include antioxidant, anti-cancer, anti-diabetic (Sudhakar et al. 2013), anti-obesity (Hitoe and Shimoda 2017), antibacterial (Rajauria and Abu-Ghannam 2013), antimelanogenesis (Berthon et al. 2017; Thomas and Kim 2013), and antiinflammatory (Berthon et al. 2017) activities. Therefore, fucoxanthin is produced on an industrial scale as a food supplement of high economic value. Although fucoxanthin can be synthesized artificially, natural fucoxanthin is a better alternative because of its availability, environmental friendliness, and cost-effectiveness (Lourenço-Lopes et al. 2020).

Lombok waters (West Nusa Tenggara Province, Indonesia) are influenced by the Indian Sea and Pacific Sea. This condition creates a singular increase in nutrients in the coastal ecosystem of Lombok waters compared with other waters (Harvianto et al. 2015). The government promotes marine algae cultivation, mainly red algae, as the premium product of this region. In addition to red algae, attempted cultivation of brown algae has also been undertaken, but these efforts did not yield promising results and were eventually ceased. The development of brown algae has been hindered by the lack of information on fucoxanthin diversity and yield. To begin production, knowledge of the algae species that perform best in 
fucoxanthin quality and quantity is crucial. Several studies have reported fucoxanthin's content and the factors that influence its production (Lourenço-Lopes et al. 2020). Each algal species has a different fucoxanthin yield, depending on the environment (Lourenço-Lopes et al. 2020), solvent (Ismail et al. 2016), and treatment process (Ismail et al. 2016; Susanto et al. 2016). The higher the fucoxanthin content, the higher the biological activity (Sivagnanam et al. 2015). Therefore, it is deemed necessary to determine the fucoxanthin proportion of several brown algae in the Lombok waters. This work focused on the quantitative comparison of fucoxanthin's proportion from several brown algae to determine fucoxanthin content diversity.

\section{MATERIALS AND METHODS}

\section{Study area}

The study area was located at Ekas Bay (Figure 1), the largest bay in Lombok Island $\left(>50 \mathrm{~km}^{2}\right.$; Setyawidati et al. 2018), West Nusa Tenggara Province, Indonesiawhich has a large distribution area for brown algae. This semienclosed bay is directly adjacent to the Indian Ocean and is traversed by currents from the Pacific Ocean. Currently, it is used as a strategic aquaculture location for several kinds of marine life, whereas the land area is primarily residential and agricultural. The algae sampling locations were along the shoreline (influenced by tides) to a depth of $3 \mathrm{~m}$ (always inundated). The location coordinates are $-8^{\circ} 52^{\prime} 29^{\prime \prime}$, $116^{\circ} 27^{\prime} 14^{\prime \prime}$; $-8^{\circ} 50^{\prime} 54^{\prime \prime}, 116^{\circ} 23^{\prime} 37^{\prime \prime}$ and $-8^{\circ} 52^{\prime} 52^{\prime \prime}, 116^{\circ} 27^{\prime} 7^{\prime \prime}$.

\section{Procedures}

\section{Sample preparation}

Three species of brown algae were cleaned from substrate materials and attached epiphytic animals. Each species was identified using molecular analysis (following Yoshida et al. 2000) and prepared for fucoxanthin purification. The samples were cut using scissors to obtain materials measuring $1 \mathrm{~cm}$ each.

\section{Pigments extraction}

Two hundred and fifty grams $(250 \mathrm{~g})$ of the leaves were macerated using a solvent mixture (acetone: methanol (3:7, v/v)) (Haugan et al. 1992). The leaves part was known to have the highest fucoxanthin content (Zailanie and Purnomo 2017), $\mathrm{Ca}_{2} \mathrm{CO}_{3}$ as a neutralizing reagent, and vitamin $\mathrm{C}$ antioxidant was added to avoid pigment degradation. The extract was then partitioned using a mixture of diethyl ether, water, and a saturated salt solution. The diethyl ether fraction (green fraction) was maintained as a crude extract. It was dried using nitrogen gas and stored at $5{ }^{\circ} \mathrm{C}$ until analyses.

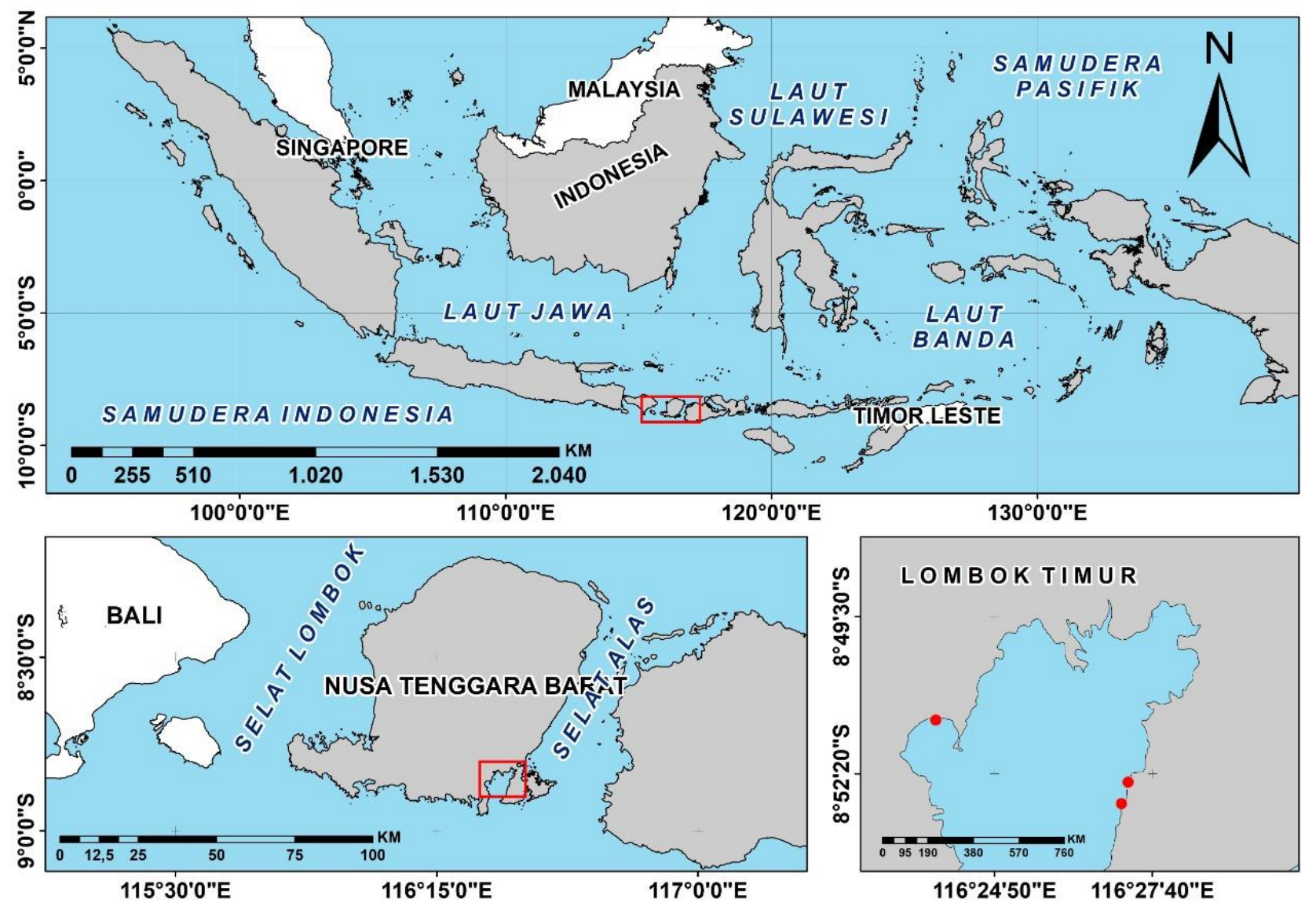

Figure 1. Ekas Bay, Lombok, Indonesia indicating the sampling sites of brown algae (red dots) 
Table 1. HPLC parameters

\begin{tabular}{ll}
\hline Parameters & Condition \\
\hline Column & YMC-Triat C18 $(250 \mathrm{~mm} \times 4.6 \mathrm{~mm}, 5 \mu \mathrm{m})$ \\
Mobile phase & Methanol: Acetonitrile $(70: 30)$ \\
Flow rate & $1 \mathrm{~mL} / \mathrm{min}$ \\
Column temp. & $30^{\circ} \mathrm{C}$ \\
Detector & $\mathrm{UV}-$ Vis Detector $(\lambda=450 \mathrm{~nm})$ \\
Injection volume & $20 \mu \mathrm{L}$ \\
Running time & 6 minutes \\
\hline
\end{tabular}

\section{HPLC analysis}

Fucoxanthin content was analyzed qualitatively using high-performance liquid chromatography (HPLC). The procedure followed the specifications of HPLC conditions by Terasaki et al. (2009), with a silica particle size of $5 \mu \mathrm{m}$. The crude extract $(0.5 \mathrm{mg})$ was dissolved in $5 \mathrm{~mL}$ of methanol and filtered. Approximately $20 \mu \mathrm{L}$ of the extract was injected into the HPLC column. Pigment composition was detected at $450 \mathrm{~nm}$. Fucoxanthin detection was based on the chromatogram's peak area, compared with the standard fucoxanthin curve $\left(\mathrm{C}_{42} \mathrm{H}_{58} \mathrm{O}_{6}\right.$; NATChrom). This standard was an all-trans fucoxanthin pigment prepared from Padina australis with a purity of 99\%. HPLC conditions used at this work is shown in Table 1.

\section{Fucoxanthin purification}

Fucoxanthin purification was executed by the column chromatography procedure of Lourenco-Lopes et al. (2020) with modifications. This analysis was conducted in two steps to maximize separation:

The liquid-liquid separation step was performed to partition non-polar fractions. Methanol $(5-10 \mathrm{~mL})$ was added to dissolve the crude extract and then partitioned using $50 \mathrm{~mL}$ of $\mathrm{n}$-hexane solvent. The methanol fraction was collected and subjected to column chromatography analysis. This step was conducted to separate the non-polar fractions properly.

The column chromatography procedure started by soaking the silica gel overnight in n-Hexane before use. The n-Hexane usage was to make sure the non-polar compounds are eliminated. The fractions were partitioned using a combination solvent of ethyl acetate and methanol $(3: 1, \mathrm{v} / \mathrm{v})$. Firstly, ethyl acetate was applied to eliminate fucoxanthin from the column. The solvents pouring was passed via the column side slowly so that the silica bed is not disturbed. After the solvent's addition, an orange and green fraction was separated, and the active target was the orange fraction. The green part is more polar than the orange. Every $10 \mathrm{~mL}$ out of the column faucet is separated during the process to ensure that the fucoxanthin is pure. Solvent addition was performed gradually to avoid mixing with more polar compounds. All processes were conducted under minimum light conditions.

\section{TLC analysis}

Thin-layer chromatography (TLC) followed Rajauria and Abu-Ghannam(2013) procedure with slight modification. This analysis was performed to confirm the presence and composition of fucoxanthin. The pigment's crude extract was analyzed using silica gel $\mathrm{GF}_{254}$ (stationary phase) and a solvent combination of hexane: ethyl acetate: methanol $(6: 3: 1 ; \mathrm{v} / \mathrm{v} / \mathrm{v}$; mobile phase). The pigments' color spots were visualized under daylight, and the retardation factor (Rf) value was calculated.

\section{Spectra absorption analysis}

The analysis procedure of Li et al. (2018) was used in this section. Spectra absorption analysis is to determine the spectra pattern and absorption of fucoxanthin by Uv-Vis spectroscopy measurement. Pure fucoxanthin was diluted in $3 \mathrm{~mL}$ ethanol. The dilution was determined in the wavelength range of 300 to $600 \mathrm{~nm}$. Spectra absorption of each peak was observed, compared with the fucoxanthin standard.

\section{Data analysis}

All measurements were performed in triplicate, and all data values are expressed as the mean \pm standard deviation. The fucoxanthin content data were analyzed statistically using a t-test $(\alpha<0.05)$ (PSPP Software Statistical Analysis).

\section{RESULTS AND DISCUSSION}

\section{Crude pigment extraction}

Three brown algae species were identified molecularly as Sargassum cf. granuliferum, Sargassum polycystum, and Sirophysalis trinodis (Figure 2). Crude extracts of pigments from fresh brown algae from Ekas Bay were prepared in acetone:methanol solvent $(3: 7, \mathrm{v} / \mathrm{v})$. The estimated yields of the extracts of $S$. cf. granuliferum, $S$. polycystum, and Sirophysalis trinodis were $1.43 \pm 0.01 \mathrm{~g} / 100 \mathrm{~g}, 1.24 \pm 0.01$ $\mathrm{g} / 100 \mathrm{~g}$, and $1.48 \pm 0.01 \mathrm{~g} / 100 \mathrm{~g}$, respectively.

\section{HPLC analysis}

The HPLC chromatogram HPLC for fucoxanthin was launched at $450 \mathrm{~nm}$. As shown in Figure 3, the chromatogram indicates that the peak pattern and resembling retention time were the same as the fucoxanthin standard. The retention time of $S$. cf. granuliferum, $S$. polycystum, and Sirophysalis trinodis was 3.095, 3.091 and fucoxanthin standard was $3.00 \mathrm{~min}$.

\section{Fucoxanthin purification}

Column chromatography was performed to purify fucoxanthin using n-hexane, ethyl acetate, and methanol as the solvents. Initially, the crude extract was partitioned into $\mathrm{n}$-hexane and methanol. The non-polar $\mathrm{n}$-hexane fraction was discarded, whereas the methanol fraction was subjected to column chromatography. The methanol fraction contained green and orange pigments. Green indicated chlorophyll c, whereas orange indicated fucoxanthin. Afterward, the rich fucoxanthin extract (methanol fraction) was gradually separated, and orange pigments were targeted. The final pure fucoxanthin was then weighed (Table 2). 


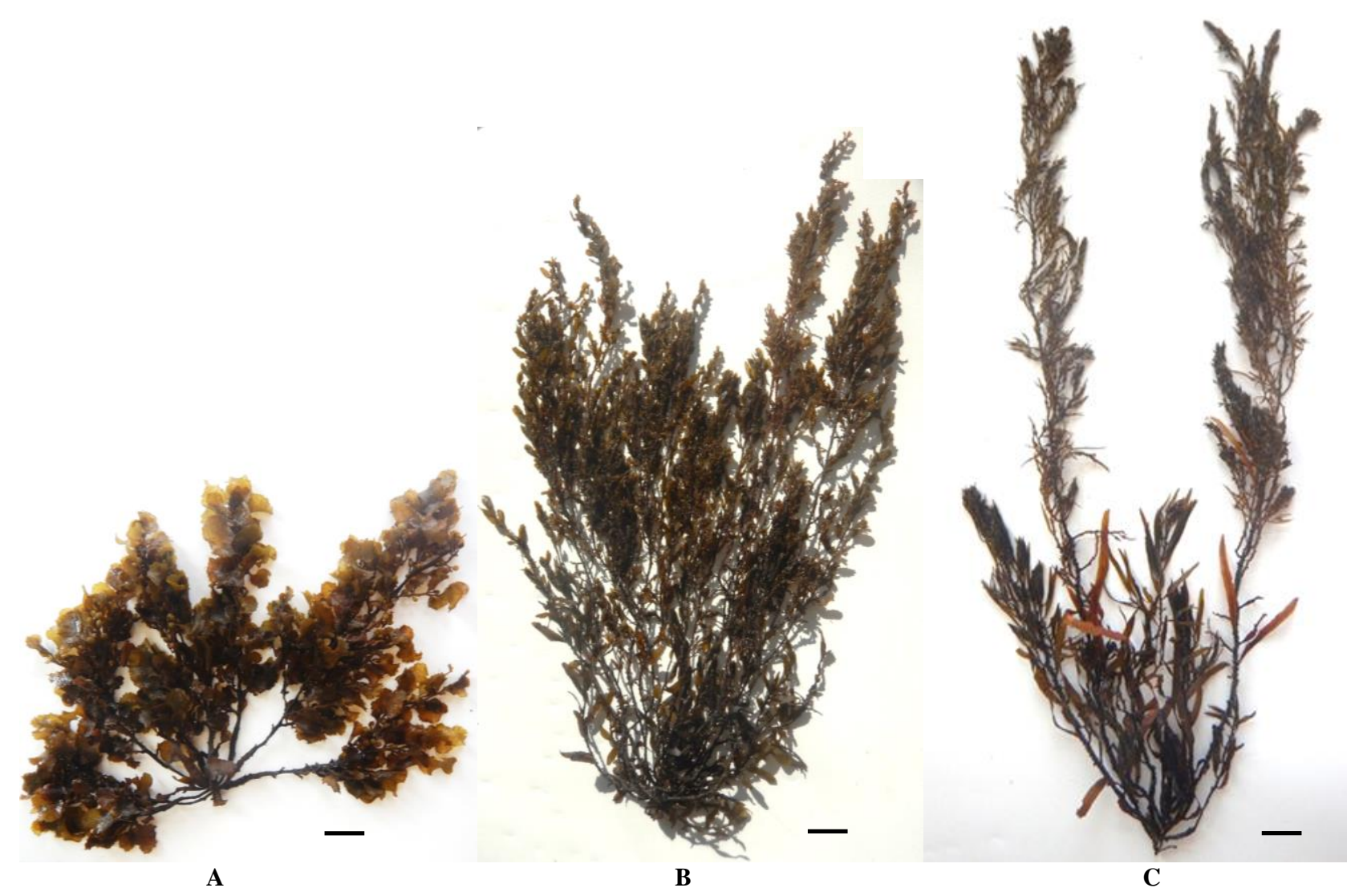

Figure 2. Brown algae commonly found in Lombok-Indonesia, A. Sargassum cf. granuliferum; B. Sargassum polycystum, and C. Sirophysalis trinodis. Bar $=2 \mathrm{~cm}$
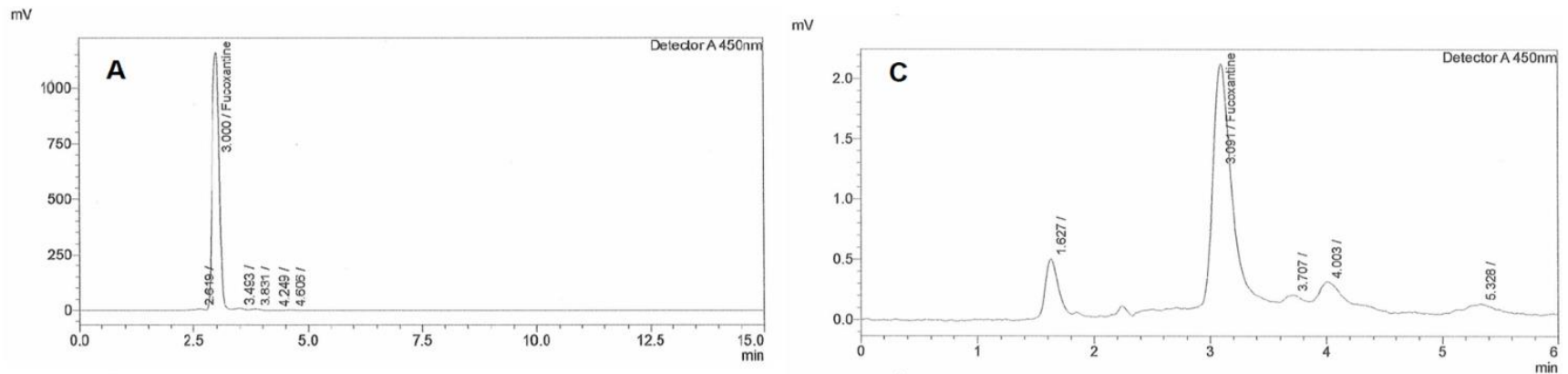

$\mathrm{mV}$

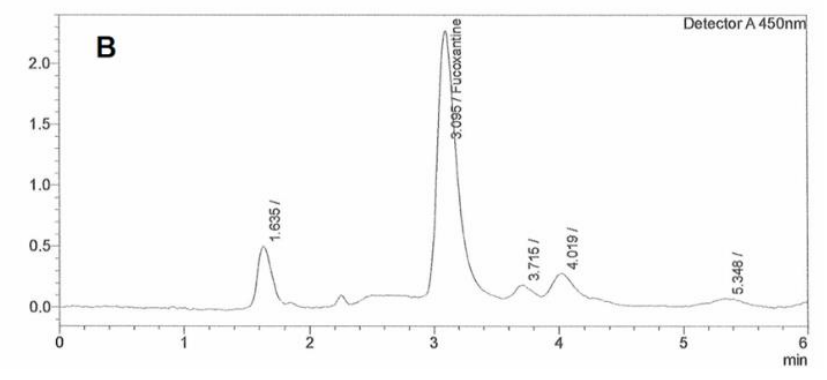

$\mathrm{mV}$

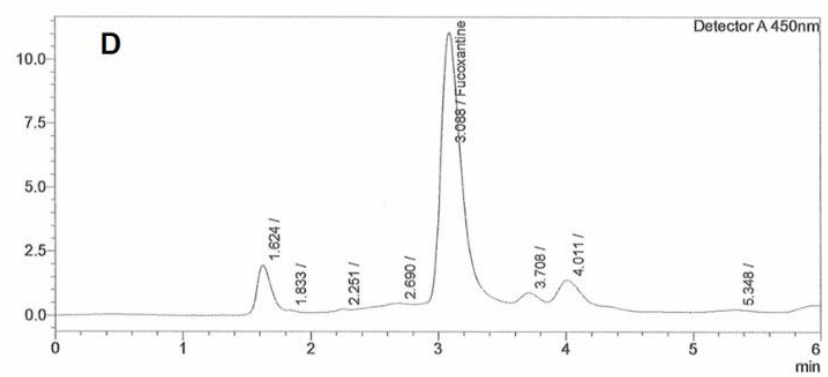

Figure 3. Chromatogram of brown algae crude extract. A. Fucoxanthin standard; B. S. cf. granuliferum; C. S. polycystum, D. Sirophysalis trinodis 


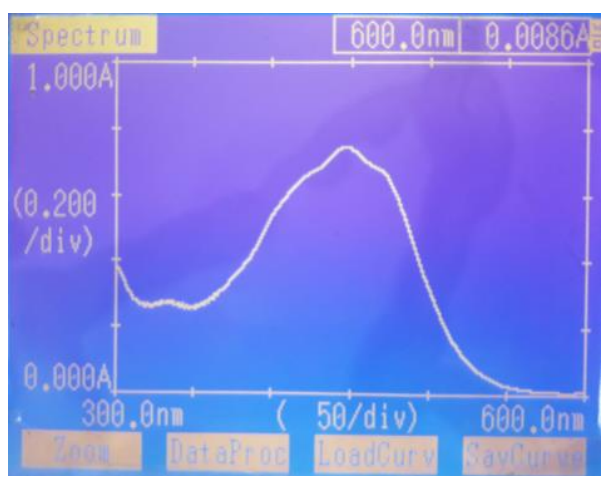

A

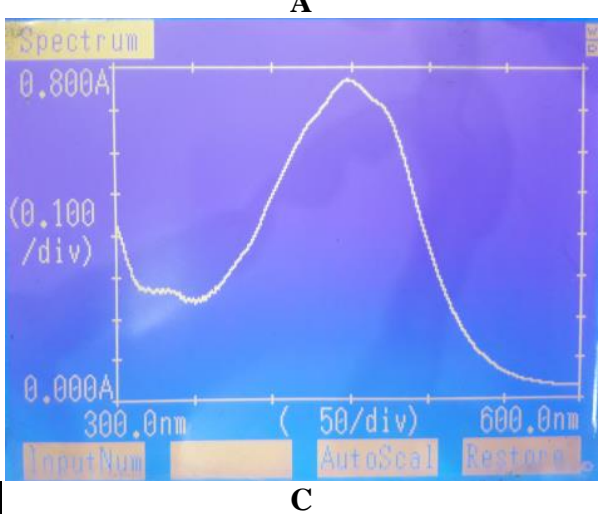

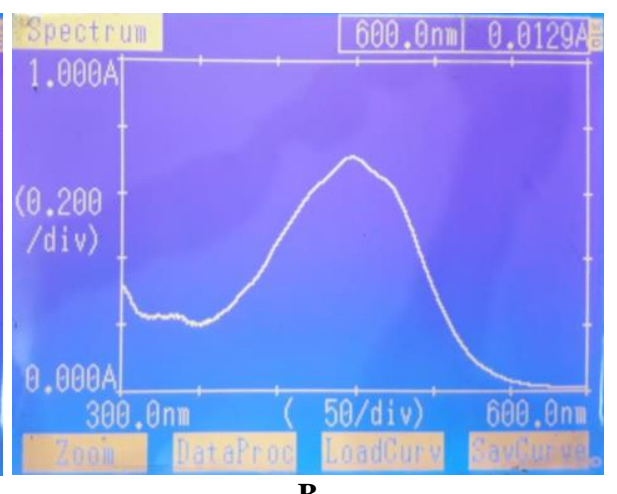

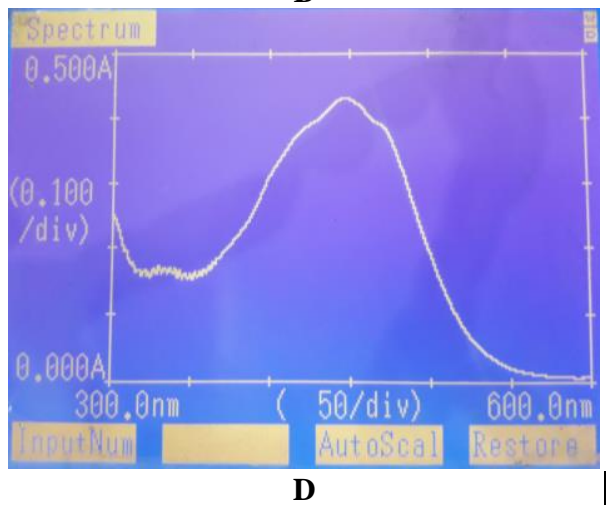

Figure 4. Fucoxanthin spectrum pattern. A. Fucoxanthin standard; B. S.cf. granuliferum; C. S. polycystum, D. Sirophysalis trinodis

Table 2. Fucoxanthin content of three brown algae from Lombok waters, Indonesia

\begin{tabular}{ll}
\hline Species & Fucoxanthin $(\mathbf{m g} / \mathbf{g})$ \\
\hline S. cf. granuliferum & $2,21 \pm 0,002^{\mathrm{a}}$ \\
S. polycystum & $3,01 \pm 0,01^{\mathrm{b}}$ \\
Sirophysalis trinodis & $0,95 \pm 0,01^{\mathrm{c}}$ \\
\hline Note: Different letters (a, b, and c) indicate a significant
\end{tabular}

Note: Different letters $(\mathrm{a}, \mathrm{b}$, and $\mathrm{c})$ indicate a significant difference in fucoxanthin content (t-test, $\alpha<0.05)$

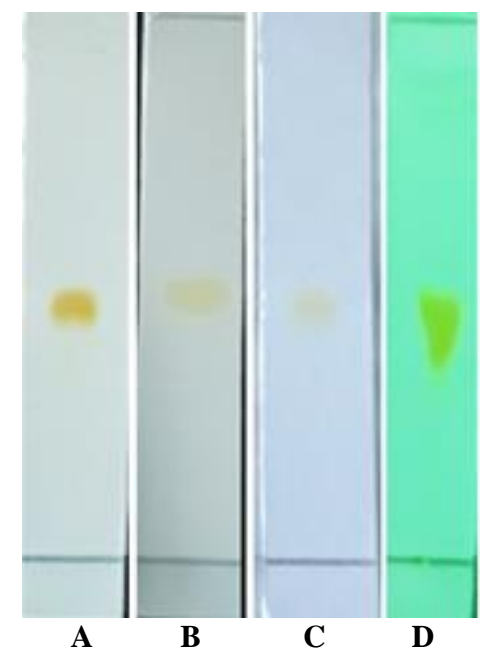

Figure 5. TLC analysis of brown algae fucoxanthin. A. Fucoxanthin standard; B. S.cf. granuliferum; C. S. polycystum, D. Sirophysalis trinodis

\section{Spectra absorption analysis}

Pure fucoxanthin was identified by using spectra absorption maxima and spectra pattern. The spectrum pattern of fucoxanthin was compared with the fucoxanthin standard. The spectra absorption of fucoxanthin standard was $447.6 \mathrm{~nm}$. The spectra absorption maxima for Sargassum cf. granuliferum, Sargassum polycystum and C. Sirophysalis trinodis was $448.2 \mathrm{~nm}, 448.4 \mathrm{~nm}$ and 447.6 $\mathrm{nm}$, respectively. The spectrum pattern is shown in Figure 4.

\section{TLC analysis}

The TLC analysis was performed by using the same solvent composition as the chromatographic column. Rf value of each algae species fucoxanthin was observed and compared by the Fucoxanthin standard Rf. The Rf value of standard was 0.46, followed by Sargassum cf. granuliferum, Sargassum polycystum, and C. Sirophysalis trinodis was $0.47,0.46$ and 0.46 , respectively. The TLC analysis result was shown in Figure 5.

\section{Discussion}

The species studied herein were brown algae commonly found in Lombok waters, i.e., S. cf. granuliferum, $S$. polycystum, and Sirophysalis trinodis. They were molecularly identified by the procedures described by Yoshida et al. (2000). Ekas Bay is dominated by this vegetation extending from the east to the center. The water body is characterized by low water turbidity and low suspended material (Setyawidati et al. 2018). 
The estimated yield of brown algae extract in this study was almost the same as that of other brown algae with different solvents. Sivagnanam et al. (2015) reported that the estimation yield of Sargassum japonica's crude extract was $1.24 \pm 0.06 \mathrm{~g} / 100 \mathrm{~g}$, and Sargassum horneri was 1.42 $\pm 0.08 \mathrm{~g} / 100 \mathrm{~g}$. The solvent used was acetone: methanol $(1: 1, \mathrm{v} / \mathrm{v})$. Whereas using hexane solvent, S. japonica's estimation yield was $1.22 \pm 0.12 \mathrm{~g} / 100 \mathrm{~g}$, and $S$. horneri was $1.36 \pm 0.14 \mathrm{~g} / 100 \mathrm{~g}$.

There are a few items that need to be considered regarding pigment identification in this work, including (i) HPLC used the retention time and peak, which were then compared with those the standard pigments; (ii) TLC used the pop-up spot and Rf, and (iii) Spectra absorption used to determine the absorption peak. Combining these methods allowed us to confirm the fucoxanthin more precisely. Indeed, numerous studies have applied these powerful methods (Abu-Ghannam and Rajauria 2013; Kartikaningsih et al. 2017; Li et al. 2018; Peraman and Nachimuthu 2019).

Yip et al. (2014) confirmed that TLC and HPLC data could ascertain fucoxanthin in the crude extract. Another prominent peak appeared close to all-trans fucoxanthin's peak (Figure 3). Those peaks exhibited the presence of fucoxanthin cis isomers. As shown in Figure 3, retention times in S. cf. granuliferum were 3.715, 4.019, and 5.348, S. polycystum 3.707, 4.003, and 5.328, and Sirophysalis trinodis 3.708, 4.011, and 5.348. Similar peaks of cisisomer fucoxanthin were also detected on Cystoseira hakodatensis and S. horneri. According to the HPLC result at a retention time of 6.8-7.7 $\mathrm{min}$ (Terasaki et al. 2012), Sargassum binderi at 3.260-4.052 $\mathrm{min}$, and Undaria pinnatifida at 5.5-6 min (Piovan et al. 2013).

In the final purification, the pigment sequence was determined using the TLC analysis. The fucoxanthin was compared using the fucoxanthin standard to ensure the fraction target. The TLC analysis was launched at the same chamber and at the same time to avoid any $\mathrm{Rf}$ variation (Rao and Shil 2019). The pure fucoxanthin reserved has the same $\mathrm{Rf}$ value as the standard. It presumed that the fucoxanthin was the same as the standard. The highest fucoxanthin content was obtained from $S$. polycystum at $3.01 \pm 0.01 \mathrm{mg} / \mathrm{g}$, followed by $S$. cf. granuliferum and Sirophysalis trinodis. Even though the brown algae were from the same bay, the fucoxanthin yields varied. The diversity of fucoxanthin content could depend on the algae species, location, and season (Terasaki et al. 2017). Comparing brown algae from tropical waters, Terasaki et al. (2017) showed that fucoxanthin production was higher in winter, particularly under low-light exposure intensity. The fucoxanthin yield in this study was relatively high compared with several other species (Table 3).

The high yield of fucoxanthin of $S$. polycystum is presumed to be caused by its very high density, reaching $219.75 \mathrm{ind} / \mathrm{m}^{2}$, compared with $S$. cf. granuliferum $(13.25$ ind $/ \mathrm{m}^{2}$ ) and Sirophysalis trinodis $\left(10.5 \mathrm{ind} / \mathrm{m}^{2}\right)$. The high individual density of $S$. polycystum leads to high competition for light for photosynthesis.
Table 3. Fucoxanthin concentration of brown algae

\begin{tabular}{lll}
\hline \multicolumn{1}{c}{ Species } & $\begin{array}{l}\text { Fucoxanthin } \\
\text { yield (mg/g) }\end{array}$ & \multicolumn{1}{c}{ References } \\
\hline Sargassum binderi & $0.73 \pm 0.39$ & Jaswir et al. (2012) \\
Sargassum duplicatum & $1.01 \pm 0.10$ & Jaswir et al. (2012) \\
Sargassum polycystum & 0.248 & Limantara (2010) \\
Sargassum thunbergii & $1.5 \pm 0.2$ & Wang et al. (2017) \\
Padina sp & $0.38 \pm 0.046$ & Sudhakar et al. (2013) \\
Turbinaria sp & $0.38 \pm 0.046$ & Sudhakar et al. (2013) \\
\hline
\end{tabular}

Therefore, fucoxanthin production could increase the efficiency of sunlight capture. Malta et al. (2003) stated there is a trend of increasing photosynthetic pigment content along with the increasing demand for sunlight. Moreover, it is supposed that this high density causes stress on algae. High density is one of the algae's biotic stresses, even causing algal death (Andrew and Viejo 1998; PérezPérez et al. 2012). Algal mechanisms when dealing with stress is antioxidant management. Antioxidant production, such as fucoxanthin, is increased to prevent excess reactive oxygen species production (Rezayian et al. 2019). Similar presumes supported by Erdoğan et al. (2016), enrichment of fucoxanthin production could be observed by enhancing oxidative stress conditions.

Sargassum polycystum is highly influenced by tides, being submerged at high tide and exposed at low tide. This situation can trigger oxidative stress and stimulate the increased secretion of fucoxanthin. Fucoxanthin is a secondary metabolite secreted because of ecological responses (Sampaio et al. 2016) and exposure to waves (Misurcova 2011). Additionally, its growth on the beach is close to residential areas, around coastal waters dominated by densely populated settlements and agricultural activities. This condition allows increased nutrient availability from the mainland and leads to a high secretion of secondary metabolite, as noted by Boderskov et al. (2015); algae with the highest fucoxanthin grow in areas with high nutrient availability.

In conclusion, our results showed that the fucoxanthin yield of three species of brown algae was diverse. $S$. polycystum has the highest fucoxanthin yield, followed by S. cf. granuliferum and Sirophysalis trinodis, as supported by biotic and abiotic factors, high population density, tides, and nutrient availability. The study could have implications for the use of $S$. polycystum as a crop for fucoxanthin production. However, these results need to be verified by directly collecting biotic and abiotic data in the field.

\section{ACKNOWLEDGEMENTS}

The authors gratefully acknowledge the funding received from the Doctoral Program of the Central Java Local Government. This work was also supported by the Directorate General of Higher Education of the Republic of Indonesia for the Doctoral Dissertation Research (Grant number 225-15/UN7.6.1/PP/2020). The authors are grateful to the Tropical Marine Biodiversity Laboratory Team 
(Faculty of Fisheries and Marine Science, Diponegoro University) for their technical assistance and comments. The authors thank Bayu Munandar for his help in map design.

\section{REFERENCES}

Abu-Ghannam N, Rajauria G. 2013. Antimicrobial activity of compounds isolated from algae. In: Dominguez $\mathrm{H}$ (ed.): Functional Ingredient from Algae for Foods and Nutraceuticals. Woodhead Publishing Limited, Cambridge. DOI: 10.1533/9780857098689.2.287.

Andrew N, Viejo R. 1998. Effects of wave exposure and intraspecific density on the growth and survivorship of Sargassum muticum (Sargassaceae: Phaeophyta). Eur J Phycol. 33 (3): 251-258. DOI: 10.1080/09670269810001736753.

Berthon JY, Nachat-Kappes R, Bey M et al. 2017. Marine algae as attractive source to skincare. Free Radic Res 51 (6): 555-567. DOI: 10.1080/10715762.2017.1355550.

Boderskov T, Schmedes P, Bruhn A et al. 2016. The effect of light and nutrient availability on growth, nitrogen, and pigment contents of Saccharina latissima (Phaeophyceae) grown in outdoor tanks, under natural variation of sunlight and temperature, during autumn and early winter in Denmark. J Appl Phycol 28: 1153-1165. DOI: 10.1007/s10811-015-0673-7

El Gamal AA. 2010. Biological importance of marine algae. Saudi Pharma J 18 (1): 1-25. DOI: 10.1016/j.jsps.2009.12.001

El Shoubaky GA, Salem EA. 2014. Terpenes and sterols composition of marine brown algae Padina pavonica (Dictyotales) and Hormophysa triquetra (Fucales). Int J Pharmacogn Phytochem Res. 6 (4): 894-900.

Erdoğan A, Demirel Z, Dalay M, Eroglu A. 2016. Fucoxanthin Content of Cylindrotheca closterium and Its Oxidative Stress Mediated Enhancement. Turkish J Fish Aquat Sci 16. DOI: 10.4194/1303-2712v16_3_01

Fertah M, Belfkira A, Dahmane, E et al. 2017. Extraction and characterization of sodium alginate from Moroccan Laminaria digitata brown seaweed. Arab J Chem 10: S3707-S3714. DOI: 10.1016/j.arabjc.2014.05.003

Go H, Hwang HJ, Nam TJ. 2010. A glycoprotein from Laminaria japonica induces apoptosis in HT-29 colon cancer cells. Toxicol in Vitro 24 (6): 1546-1553. DOI: 10.1016/j.tiv.2010.06.018

Harvianto L, Parengkuan M, Koropitan AF, Agustiadi T. 2015. Analisis diagram T-S berdasarkan parameter oseanografis di perairan selat Lombok. Surya Octagon Interdisciplinary 1 (1): 103-119. [Indonesian]

Haugan JA, Aakermann T, Liaaen-Jensen SB. T.-M. in E. 1992. Isolation of fucoxanthin and peridinin. In Carotenoids Part A: Chemistry, separation, quantitation, and antioxidation. Academic Press, Cambridge. DOI: 10.1016/0076-6879 (92)13124-G

Hitoe S, Shimoda H. 2017. Seaweed fucoxanthin supplementation improves obesity parameters in mildly obese japanese subjects. Funct Food Health Dis 7 (4): 246-262.

Ismail N, Abdullah A, Suri R. 2016. Effects of drying methods, solvent extraction and particle size of Malaysian brown seaweed, Sargassum sp. on the total phenolic and free radical scavenging activity. Int Food Res J 23: 1558-1563.

Jaswir I, Noviendri D, Salleh HM, Miyashita K. 2012. Fucoxanthin extractions of brown seaweeds and analysis of their lipid fraction in methanol. Food Sci Technol Res 18 (2): 251-257. DOI 10.3136/fstr.18.251.

Kadam SU, Donnell CPO, Rai DK et al. 2015. Laminarin from Irish Brown Seaweeds Ascophyllum nodosum and Laminaria hyperborea. Obesity, Fitness Wellness Week 13 (7): 4270-4280. DOI: 10.3390/md1307427.

Kartikaningsih H, Mufti ED, Nurhanief AE. 2017. Fucoxanthin from brown seaweed Sargassum cristaefolium tea in acid pH. AIP Conf Proc 1844: 4983436. DOI: 10.1063/1.4983436.

Kim JA, Ahn BN, Kong CS, Kim SK. 2012. Protective effect of chromene isolated from Sargassum horneri against UV-A-induced damage in skin dermal fibroblasts. Exp Dermatol 21 (8): 630-631. DOI 10.1111/j.1600-0625.2012.01535.x
Li FL, Wang LJ, Fan Y et al. 2018. A rapid method for the determination of fucoxanthin in diatom. Mar Drugs 16 (1): 1-13. DOI: $10.3390 / \mathrm{md} 16010033$.

Limantara L. 2010. Studi komposisi pigmen dan kandungan fukosantin rumput laut cokelat dari perairan madura dengan kromatografi cair kinerja tinggi. Indon J Mar Sci 15 (1): 23-32.

Lourenço-Lopes C, García Oliveira P, Rodríguez M et al. 2020. Scientific approaches on extraction, purification and stability for the commercialization of fucoxanthin recovered from brown algae. Food 9: 1113. DOI: 10.3390/foods9081113.

Malta E, Rijstenbil J, Brouwer PEM, Kromkamp J. 2003. Vertical heterogeneity in physiological characteristics of Ulva spp. mats. Mar Biol 143, 1029-1038. DOI: 10.1007/s00227-003-1134-4.

Mikami K, Hosokawa M. 2013. Biosynthetic pathway and health benefits of fucoxanthin, an algae-specific xanthophyll in brown seaweeds. Int J Mol Sci 14 (7): 13763-13781. DOI: 10.3390/ijms140713763.

Misurcova L. 2011. Chemical composition of seaweeds. In Handbook of Marine Macroalgae: Biotechnology and Applied Phycology. John Wiley \& Sons, New Jersey. DOI: 10.1002/9781119977087.ch7.

Muranaka T, Saito K. 2010. Production of pharmaceuticals by plant tissue cultures. In: Mander L, Liu HW (eds.). Comprehensive Natural Products II. Reference Module in Chemistry, Molecular Sciences and Chemical Engineering. Elsevier, Kidlington.

Peng J, Yuan JP, Wu CF, Wang JH. 2011. Fucoxanthin, a marine carotenoid present in brown seaweeds and diatoms: metabolism and bioactivities relevant to human health. Mar Drugs 9 (10): 1806-1828. DOI: $10.3390 / \mathrm{md} 9101806$.

Peraman M, Nachimuthu S. 2019. Identification and quantification of fucoxanthin in selected carotenoid-producing marine microalgae and evaluation for their chemotherapeutic potential. Pharmacogn Mag 15 (64): S243-249. DOI: 10.4103/pm.pm_64_19.

Pérez-Pérez ME, Lemaire SD, Crespo JL. 2012. Reactive oxygen species and autophagy in plants and algae. Plant Physiol 160 (1): 156-164. DOI: $10.1104 /$ pp.112.199992.

Rajauria G, Abu-Ghannam N. 2013. Isolation and partial characterization of bioactive fucoxanthin from Himanthalia elongata brown seaweed: A TLC-based approach. Intl $J$ Anal Chem. DOI: $10.1155 / 2013 / 802573$.

Rao MRK, Shil S. 2019. Study of alkaloid (nicotine): in various smoking articles by thin-layer chromatography. Drug Invent Today 11 (5): 1214-1217.

Rezayian M, Niknam V, Ebrahimzadeh H. 2019. Oxidative damage and antioxidative system in algae. Toxicol Rep 6: 1309-1313. DOI: 10.1016/j.toxrep.2019.10.001

Ritter A, Goulitquer S, Salaün JP, Tonon T, Correa JA, Potin P. 2008. Copper stress induces biosynthesis of octadecanoid and eicosanoid oxygenated derivatives in the brown algal kelp Laminaria digitata. New Phytol $180 \quad$ (4): 809-821. DOI: 10.1111/j.14698137.2008.02626.x

Sampaio BL, Edrada-Ebel R, Da Costa FB. 2016. Effect of the environment on the secondary metabolic profile of Tithonia diversifolia: A model for environmental metabolomics of plants. Sci Rep 6: 29265. DOI: 10.1038/srep29265.

Setyawidati NAR, Puspita M, Kaimuddin AH et al. 2018. Seasonal biomass and alginate stock assessment of three abundant genera of brown macroalgae using multispectral high resolution satellite remote sensing: A case study at Ekas Bay (Lombok, Indonesia). Mar Pollut Bull 131: 40-48. DOI: 10.1016/j.marpolbul.2017.11.068.

Shi D, Li X, Li J, Guo S, Su H, Fan X. 2010. Antithrombotic effects of bromophenol, an alga-derived thrombin inhibitor. Chinese J Oceanol Limnol 28 (1): 96-98. DOI: 10.1007/s00343-010-9213-0.

Sivagnanam SP, Yin S, Choi JH et al. 2015. Biological properties of fucoxanthin in oil recovered from two brown seaweeds using supercritical $\mathrm{CO}_{2}$ extraction. Mar Drugs 13 (6): 3422-3442. DOI: $10.3390 / \mathrm{md} 13063422$.

Stiger-Pouvreau V, Jégou C, Cérantola S, Guérard F, Lann K. Le. 2014. Phlorotannins in Sargassaceae species from Brittany (France): Interesting molecules for ecophysiological and valorization purposes. Adv Bot Res71: 379-411. DOI: 10.1016/B978-0-12-408062-1.000135 .

Sudhakar MP, Ananthalakshmi JS, Nair BB. 2013. Extraction, purification and study on antioxidant properties of fucoxanthin from brown seaweeds. J Chem Pharm Res 5 (7): 169-175.

Susanto E, Fahmi AS, Abe M, Hosokawa M, Miyashita K. 2016. Lipids, fatty acids, and fucoxanthin content from temperate and tropical 
brown seaweeds. Aquat Procedia 7: 66-75. DOI: 10.1016/j.aqpro.2016.07.009.

Tanniou A, Vandanjon L, Incera M et al. 2014. Assessment of the spatial variability of phenolic contents and associated bioactivities in the invasive alga Sargassum muticum sampled along its European range from Norway to Portugal. J Appl Phycol 26 (2): 1215-1230. DOI: 10.1007/s10811-013-0198-x.

Terasaki M, Hirose A, Narayan B et al. 2009. Evaluation of recoverable functional lipid components of several brown seaweeds (Phaeophyta) from Japan with special reference to fucoxanthin and fucosterol contents. J Phycol 45 (4): 974-980. DOI: 10.1111/j.15298817.2009.00706.x.

Terasaki M, Kawagoe C, Ito A et al. 2017. Spatial and seasonal variations in the biofunctional lipid substances (fucoxanthin and fucosterol) of the laboratory-grown edible Japanese seaweed (Sargassum horneri Turner) cultured in the open sea. Saudi J Biol Sci 24 (7): 1475-1482. DOI: $10.1016 /$ j.sjbs.2016.01.009.

Terasaki M, Narayan B, Kamogawa H, Nomura M, Stephen N, Kawagoe C, Hosokawa M, Miyashita K. 2012. Carotenoid profile of edible japanese seaweeds: An improved HPLC method for separation of major carotenoids. J Aquat Food Prod Technol 21(5): 468-479. DOI: 10.1080/10498850.2011.610025.

Thomas NV, Kim SK. 2013. Beneficial effects of marine algal compounds in cosmeceuticals. Mar Drugs 11 (1): 146-164. DOI $10.3390 / \mathrm{md} 11010146$

Wang $\mathrm{X}, \mathrm{Li} \mathrm{H}$, Wang $\mathrm{F}$ et al. 2017. Isolation of fucoxanthin from Sargassum thunbergii and preparation of microcapsules based on palm stearin solid lipid core. Front Mater Sci 11 (1): 66-74. DOI: $10.1007 / \mathrm{s} 11706-017-0372-1$
Wen ZS, Xiang XW, Jin HX et al. 2016. Composition and antiinflammatory effect of polysaccharides from Sargassum horneri in RAW264.7 macrophages. Intl J Biol Macromol 88: 403-413. DOI: 10.1016/j.ijbiomac.2016.02.025

Will Castro LSEP, Gomes Castro AJ, da S. Nascimento Santos M et al. 2016. Effect of galactofucan sulfate of a brown seaweed on induced hepatotoxicity in rats, sodium pentobarbital-induced sleep, and antiinflammatory activity. J Appl Phycol 28 (3): 2005-2017. DOI: 10.1007/s10811-015-0698-y.

Yip WH, Lim SJ, Mustapha WAW, Maskat MY, Said M. 2014. Characterization and stability of pigments extracted from Sargassum binderi obtained from Semporna, Sabah. Sains Malaysiana 43 (9): 1345-1354.

Yoshida T, Stiger V, Horiguchi T. 2000. Sargassum boreale sp. nov. (Fucales, Phaeophyceae) from Hokkaido, Japan. Phycol Res 48 (3): 125-131. DOI: 10.1046/j.1440-1835.2000.00197.x

Zailanie K, Purnomo H. 2017. Identification of fucoxanthin from brown algae (Sargassum filipendula) from Padike village, Talango district, Sumenep regency, Madura islands, using nuclear magnetic resonance (NMR). Intl Food Res J 24 (1): 372-378.

Zhang H, Tang Y, Zhang Yet al. 2015. Fucoxanthin: a promising medicinal and nutritional ingredient. Evid-Based Compl Altern Med 2015: 723515. DOI: $10.1155 / 2015 / 723515$

Zorofchian Moghadamtousi S, Karimian H, Khanabdali R et al. 2014. Anti-cancer and antitumor potential of fucoidan and fucoxanthin, two main metabolites isolated from brown algae. Sci World J 2014: 768323. DOI: $10.1155 / 2014 / 768323$. 